DOI: 10.20472/LPC.2018.002.001

\title{
ROMINA BEQIRI
}

European University of Tirana, Netherlands

\section{A VICTIM-ORIENTED JUSTICE DISPUTE IN THE CONTEXT OF THE JUDICIAL SYSTEM REFORM IN ALBANIA}

\begin{abstract}
:
The position and status of victims in the criminal justice process have been the subject of recent developments at the domestic, European and international levels in many aspects. The adoption of domestic legislations reflects the understanding of the challenges faced by victims and their commitment to a progressive judicial system. In this context, the recent amendments to its Code of Criminal Procedure in light of the recent Judicial System Reform by Albania seem to be a positive development towards the extensive participation of victims of crime in criminal proceedings. However, there are debates whether the right to participate is practically implemented and what is its impact on the criminal trial. This research shows the demand for the establishment of a neutral support mechanism to assist victims at all stages of the judicial process - from investigation to a final judgment. This paper addresses the perceptions and expectations of the judicial staff to address all the issues pertaining to victims' needs in and outside the criminal proceedings. This article aims: (1) to shed a light on the reasons behind the Judicial System Reform approach to amend the Code of Criminal Procedure rather than to adopt a comprehensive and comprehensible victim-oriented justice; (2) to reflect upon the role and rights of victims in the Albanian criminal justice system; and (3) to conclude with the recommendation to set up an effective long-term mechanism with the sole responsibility to provide the required support and assistance to the victims in Albania and in the context of the Kosovo Specialist Chamber.
\end{abstract}

\section{Keywords:}

victim participation, victim's rights, psycho-social assistance and protection, financial compensation, mediation

JEL Classification: K14, K33, K49 


\section{Introduction}

The moral legacy undertaken by any domestic or international tribunal is a reminder for every human being that the efforts "to ensure respect for human rights and the rule of law continue; that the cause of justice endures, and that the hope to end impunity lives on"1. Indeed, crime is a wrong against society as well as a violation of the individual rights of victims $^{2}$. In the wake of the vast Judicial Reform of 2016-2017 in Albania, there is a special legal, judicial and public awareness of the criminal proceedings involving individuals who are accused for committing crimes especially homicides, organized crime, corruption and human and drug trafficking. The truth finding process demonstrates that there is a progressive and considerable emerge of the influence of victims at least in relation to a well-established procedural right of participation within the criminal proceedings, in a manner that provides them rights and obligations almost analogous to those of the accused and the Prosecutor.

Doak (2005) ${ }^{3}$ argues that the concept of 'participation' is and abstract term and lacks a concrete definition. He correctly explains that although 'participation' in criminal justice of a third party might appear feasible and desirable but its extend is vague given that the traditionally dichotomous nature of the criminal trial between the Prosecution and the accused might not accommodate such participation. Albania has an adversarial model of justice in which a criminal trial is constructed as a litigation between two theoretically equal adversaries - the Prosecutor and the Defence - played out before an impartial adjudicator - the Judge ${ }^{4}$. According to this model and to the previous Code of Criminal Procedure (CCP), the victim was a passive participant called to testify as a witness, to respond to questions in direct and cross-examination; and as an accusing injured person or civil plaintiff for seeking compensation from the damage of the criminal offence ${ }^{5}$. With a role of principal witness for the Prosecution, until recently the victim had no further role to play in criminal proceedings ${ }^{6}$.

This article is of most significance to victims in the context of the new amendments of the CCP and within the framework of the Judicial System Reform. It takes into account the perspective of staff of the District Court of Shkodra in a questionnaire performed in November 2017.

\footnotetext{
1 "Successful Conclusion of Final ICTY Legacy Conference", 22 to 24 June 2017. Mr Miguel de Serpa Soares, UnderSecretary-General for Legal Affairs and United Nations Legal Counsel, delivered the Closing Address, reflecting on the "moral legacy" of the ICTY. http://www.icty.org/en/press/successful-conclusion-of-final-icty-legacy-conference (accessed in November 2017).

2 Directive 2012/29/EU of the European Parliament and of the Council of 25 October 2012 establishing minimum standards on the rights, support and protection of victims of crime, and replacing Council Framework Decision 2001/220/JHA.

3 Doak, J., (2005) “Victims' Rights in Criminal Trials: Prospects for Participation”, Journal of Law and Society, Vol. 32, Issue 2, pp. 294-316.

4 Erez, E., V. Roberts, J. V., (2014) “Victim Input at Sentencing”, p. 5425 in G. Bruinsma, D. Weisburd, (eds) "Encyclopedia of Criminology and Criminal Justice", Springer.

5 Anastasi, A. "Te Drejtat e Viktimave te Trafikimit te Qenieve Njerezore ne Procesin Penal (neni 58, 58/b te Kodit te Procedures Penale) in "Komentar I Veprave Penale te Trafikimit te Qenieve Njerezore", p.

${ }^{6}$ lbid.
} 
Whilst the Albanian legal approach seems to be a positive step forward in compliance with the United Nations Declaration of Basic Principles of Justice for Victims of Crime and Abuse of Power $(1983)^{1}$, the pressure to harmonize its provisions in conformity with the European Union Directive 2012/29/EU² (hereinafter also "the Directive") questions the constitutional and legal challenge which is related to the extent to which the Judicial System Reform has legitimated appropriately the legislation on victims' rights. Despite the fact that the new developments aimed to reinforce the position of victims complying with Directive by including changes in the terminology, extending their rights, and transforming their role from passive witnesses to active participants with rights to contribute to the proceedings, there is no definition of the term 'victim' per se. Meanwhile, the definition is enshrined in the Directive's Article 2(1)(a) as:

i. a natural person who has suffered harm, including physical, mental or emotional harm or economic loss which was directly caused by a criminal offence;

ii. family members of a person whose death was directly caused by a criminal offence and who have suffered harm as a result of that person's death.

Accordingly, whether the Directive has been substantially considered in the drafting of the new amendments, it is particularly questionable in the context of defining the subject of law and his or her capacity to realize rights and judicial duties.

Mitsilegas $(2015)^{3}$ argues that to which extent the Directive can have an impact on a domestic criminal justice system considering the national legal diversity and to what extend EU directives harmonisation can challenge the national diversity. Indeed, the process of harmonisation requires not only a proper translation from English to Albanian of the provisions enshrined in the Directive or other victim international legislation, but a proper implementation of its substantial content in conformity to the highest public interest of victims. Indeed, the expectations of the potential impact of EU victims law and the Albanian reform on victims are far from being realistic due to lack of fully implementation of the institutions that ensure such rights. Further, victims' rights cannot be adopted and applied if not in conjunction with the rights of the defence and on the balance of the parties' interests in the criminal justice systems.

The novel dimension of the victims testifying in serious crime cases especially organized crime and corruption has created a climate of serious intimidation due to lack of adequate protective measures, re-victimization and public exposure through non-professional disclosure of confidential information by court officials and media. In additional, the 'confusion' among Judges and Prosecutors in the implementation of victims' rights without relevant institutions in place - Special Courts and Prosecutor for combating organized crime and corruption (SPAK) - to assist and protect them is an indicator thereby of the limitation of the protective and assistance capacity to provide adequate normative measures. As a matter of fact, there are no practical support measures for the

\footnotetext{
${ }^{1}$ A/RES/40/34, 29 November 1985.

2 Directive 2012/29/EU of the European Parliament and of the Council of 25 October 2012 establishing minimum standards on the rights, support and protection of victims of crime, and replacing Council Framework Decision 2001/220/JHA.

${ }^{3}$ Mitsilegas, V. (2015) The Place of the Victim in the Europe's Area of Criminal Justice, p. 314 in Ippolito, F. and Sanchez, S. I. "Protecting Vulnerable Groups: The European Human Rights Framework", Publisher Bloomsbury Publishing, ISBN 178225613X, 9781782256137.
} 
protection of victims in particular for the support and recognition of victims of organized crime and terrorism.

\section{The legal scope of victims' rights in criminal proceedings}

The terminology of victims' rights departs from the notion of a legal right in the sense that it can be applied and enforced through the justice system. In conformity with EU Directive 2012/29, the new provisions in the Code of Criminal Procedure, aim to fulfil two objectives: firstly, to guarantee victims adequate information, aid, protection and, regardless of the existence of a criminal investigation; and secondly, to offer them the possibility of participating in the criminal proceedings ${ }^{1}$.

The new set of rights will give victims of crime a:

1. right to information which consists of asking for information about the judicial system, investigation and proceedings and victims services;

2. right to participation which includes the presentation of a victim impact statement and give views on decisions that affect their rights;

3. right to seek restitution in accordance with court's orders and they can be enforced through civil courts.

4. right to protection which includes consideration of their security, privacy and to have reasonable and necessary protective measures from intimidation and retaliation taken by the appropriate authorities.

The right of victims of crimes to participate in the criminal justice process was internationally recognized for the first time in 1985 when the United Nations Declaration of Basic Principles of Justice for Victims of Crime and Abuse of Power was adopted by the General Assembly². Later on, ad hoc international criminal courts and tribunals acknowledged victim participation in proceedings which was thus included in the statutory documents of the International Criminal Tribunal for the former Yugoslavia (ICTY), the Extraordinary Chambers in the Courts of Cambodia (ECCC), and the Special Tribunal for Lebanon (STL) ${ }^{3}$. More recently, the law establishing the Kosovo Specialist Chambers and the Specialist Prosecutor's Office also adopted victim participation ${ }^{4}$. However, in 1998, the founding Member States, law professors and international criminal lawyers identified

\footnotetext{
1 Allegrezza, S., (2015), Victim's Statute Within Directive 2012/29/EU, p.5, in L. Lupária (ed.), Victims and criminal justice. European standards and national good practices.

2 United Nations Declaration of Basic Principles of Justice for Victims of Crime and Abuse of Power, Resolution (40/34), adopted by the General Assembly of the United Nations on 29 November 1985, UN Doc. A/RES/40/34 ; Kinga TiboriSzabó and Megan Hirst, (2017) Introduction: Victim Participation in International Criminal Justice, p. 2; in K. TiboriSzabó and M. Hirst (eds.), Victim Participation in International Criminal Justice, International Criminal Justice Series 11, p. 2.

${ }^{3}$ Article 68(3) of the ICTY Statute; Rule 23 of the Internal Rules of the ECCC; Article 17 of the STL Statute.

${ }^{4}$ Chapter 8 'Participation of Victims in the Proceedings', Rule 113, of the Rules of Procedure and Evidence.
} 
the International Criminal Court (ICC) $)^{1}$ as a "victim court", one that would give survivors of mass atrocity an influential voice in the administration of justice ${ }^{2}$. The ICC Rome Statute ${ }^{3}$

At the European Union level, pursuant to Directive 2012/29/EU (para. 9), victims of crime should be recognized and treated in a respectful, sensitive and professional manner without any kind of discrimination such as race, colour, ethnic or social origin, genetic features, language, religion or belief, political or any other opinion, membership of a national minority, property, birth, disability, age, gender, gender expression, gender identity, sexual orientation, residence status or health.

Similarly, in the Albanian legislation, the protection of fundamental human rights, freedom and dignity, and the victim participation in criminal proceedings has assumed a constitutional human rights dimension considering that it stands at the basis of the entire juridical order ${ }^{4}$. Further, the scope of the criminal procedure legislation pursuant to Article 1 of the CCP is to guarantee fair, equal and due legal proceedings, in order to protect the freedoms and lawful rights and interests of citizens, to contribute to the strengthening of the legal order and the implementation of the Constitution and other domestic legislation (Unifying Criminal Decisions, 1999-2015:346). In accordance with Article 58 entitled 'Rights of the victim of the criminal offence', amended by Law no. 35/2017, dated 30.03.2017, victim participation in the Albanian Courts can be accomplished by enforcing their rights through the adequate implementation. In the actual situation, the main legal and practical concerns are that the benefit of having written rights on paper is actually not effective. On one hand, there is a serious lack of information for the Judges and Prosecutors as to how make victims' rights a reality in the proceedings - i.e. whether the application of victims' rights is done propio motu by the victim through an oral or written request or the judicial authorities (Prosecutor, police officer, or the Judge). On the other hand, there is no enforcement mechanism to support those rights, namely a victim unit within the Courts.

Anastasi (2017:57) $)^{5}$ classified victims' rights into two groups: rights exercised on victim's request and directly by the authorities. She argued that on his or her own initiative, the victim of a criminal offence has the right to require:

a. the prosecution of the perpetrator;

b. information at any time about the status of the proceedings, and acquainted about the acts and evidence, without breaching the principle of investigatory secret ${ }^{1}$;

\footnotetext{
1 The first permanent criminal tribunal trying hideous crimes such as war crimes, crimes against humanity, genocide and aggression.

2 Stephen Smith Cody, Alexa Koenig, and Eric Stoven "The Victims' Court: A Study of 622 Victim Participants at the International Criminal Court" November 2015.

3 The ICC was established under the Rome Statute of the International Criminal Court on July 17, 1998, 2187 U.N.T.S. 3.

${ }^{4}$ The Preamble and Article 15 of the Albanian Constitution guarantee that the fundamental human rights and freedoms are indivisible, inalienable, and inviolable and stand at the basis of the entire juridical order.

The bodies of public power, in fulfilment of their duties, shall respect the fundamental rights and freedoms, as well as contribute to their realization.

${ }^{5}$ Anastasi, A. (2017). Te Drejtat e Viktimave te Trafikimit te Qenieve Njerezore ne Procesin Penal (neni 58, 58/b te Kodit te Procedures Penale). In S. Simoni, A. Anastasi, \& E. Imeraj, Komentar I Veprave Penale te Trafikimit te Qenieve Njerezore - Te drejtat e viktimave te trafikimit gjate procesit penal (p. 57). Tirana: OSCE.
} 
c. information about the status of the proceedings and evidence;

d. to have full access to information on the investigation file;

e. to be provided with the evidence and having the right to submit other requests to the Court;

f. to file an appeal in the court against the decision of the Prosecutor for the noninitiation of the proceeding and the decision of the Prosecutor or of the Judge of the preliminary hearing to dismiss the charge or the case ${ }^{2}$;

g. to ask for compensation for the damage and be accepted as a civil plaintiff in the criminal process ${ }^{3}$;

h. to be excluded from the payment of every expense for receiving the acts and judicial fee for the submission of the lawsuit connected with the status of the victim of the criminal offence, in the cases provided for by the law.

Alternatively, the Prosecutor, the (judicial) police officer and the Judge have the authority to directly apply propio motu certain victims' rights regardless of whether the victim has submitted a request or not (Anastasi, 2017:57). Hence, the appropriate authorities in the criminal justice system should ensure the following rights:

a. to benefit of medical care, psychological assistance, counseling and other services provided by the authorities, organizations or institutions responsible for assisting the victims of criminal offense;

b. to communicate in the victim's language and to be assisted by an interpreter and an interpreter of the language of signs or communication facilitator for people for persons with disabilities in speaking and listening; to choose a defense counsel;

c. to receive free legal aid according to the legislation in force where appropriate;

d. to be informed about the arrest of the accused person and his release ${ }^{4}$;

e. to be informed of the arrest of the accused and his release under the conditions of set forth in this Code;

f. to be notified of the non-initiation of the proceedings, the dismissal of the case, the initiation and the completion of the trial;

g. to be called on the preliminary hearing and at the first session of the judiciary;

$\mathrm{h}$. to be heard by the court, even when none of the parties has requested the victim as witness.

Pursuant to Article 4 paragraph 2 of the Directive 2012/29/EU, the right to receive information from the competent authority is not absolute. As a consequence, the extent or detail of information varies depending on two factors:

a. the specific needs and personal circumstances of the victim

b. the type or nature of the crime.

\footnotetext{
1 Directive 2012/29/EU recommends states that state authorities "should not be obliged to provide information where disclosure of that information could affect the proper handling of a case or harm a given case or person, or if they consider it contrary to the essential interests of their security", para. 28.

${ }^{2}$ Article 332/gj CCP.

${ }^{3}$ Article 58, The rights of the victim of the criminal offence, Amended by Law no. 35/2017, dated 30.03.2017, Article 40. See also Directive 2012/29/EU which explains that the "information about reimbursement of expenses should be provided, from the time of the first contact with a competent authority, for example in a leaflet stating the basic conditions for such reimbursement of expenses. Member States should not be required, at this early stage of the criminal proceedings, to decide on whether the victim concerned fulfils the conditions for reimbursement of expenses", para 23

${ }^{4}$ Referring to Directive 2012/29/EU in paragraph 30-32 and Article 6(5)
} 
However, additional details can be provided at later stages of proceedings. The right to information and its restriction during the preliminary investigations is enshrined in a new provision namely Article 279/a, in which the victim, its legal representative or defense lawyer, are entitled to request information on the state of the proceedings, and to have access and receive copies of acts and evidence contained in the Prosecutor's file unless otherwise provided by the law ${ }^{1}$. Moreover, the victim is entitled to request information in relation to the application, extension, replacement or revocation of precautionary measures against the defendant, unless the notice on these facts could endanger the life or health of the defendant ${ }^{2}$.

Given that Albania is a State Party to the most relevant UN and Council of Europe (CoE) instruments ${ }^{3}$ concerning victims, the national authorities have the positive obligation to take appropriate measures to ensure that victims are treated with respect and receive effective protection at all stages of the proceedings, support and access to justice ${ }^{4}$. The novelty of the harmonization of CCP with the EU Directive is the condition of vulnerability $^{5}$. Kreuter ${ }^{6}$ (2006) considers victim vulnerability, a type of psychological disorder due to the personality and behavioral factors. Vulnerable victims are those who face an increased risk to re-suffer psychological harm through the process of testifying (making a statement as well as the appearance before a court) or re-traumatization which is related to psychosocial or physical difficulties which affects their ability to testify. The vulnerability of victims can be determined by different factors such as:

a. Factors related to the person: age (children or elderly), personality, disability (including cognitive impairments), mental illness or psychosocial problems (such as trauma-related problems and/or lack of social support).

b. Factors related to the nature of the crime, especially victims of sexual or gender-based violence, children, and victims of torture or other crimes involving excessive violence.

c. Factors related to particular circumstances, such as significantly increased stress or anxiety due to relocation/resettlement or fear of retaliation, adaptation difficulties related to cultural differences. ${ }^{7}$

The principle of protection and fair treatment of victims is an important element of justice which should be guarantee by the court and enforcement authorities. The impact of their statement also helps the Judges in the determination of sentencing, thus reflecting the

\footnotetext{
1 Article 279/a paragraph 2 provides the limitation of the right of information. Thus, the prosecutor may reject the victim's request if a) the interest of preserving the secrecy of the investigation exceeds the victim's interest; b) the interest of the defendant exceeds the victim's interest; $c$ ) the victim has not yet been examined as a witness.

2 Article 279/a para.3.

3 UNTOC, UNCC, the CoE the Criminal Law Convention on Corruption (ETS No. 173), the CoE Convention on Action against Trafficking in Human Beings (CETS No. 197), the Second Additional Protocol to the European Convention on Mutual Assistance in Criminal Matters (ETS No. 182).

4 The Directive replaces the 2001 Framework Decision on the standing of victims in criminal proceedings and considerably strengthens the rights of victims and their family members to information, support and protection and victims' procedural rights in criminal proceedings.

5 Sorgato, A. (2016), II Nuovo Statutto dei diritti della vittima, Amici della Casa dei Diritti, http://www.amicidellacasadeidiritti.it/il-nuovo-statuto-dei-diritti-della-vittima/ (Assessed in April 2018)

6 Kreuter, E. A., (2006), "Victim vulnerability : an existential-humanistic interpretation of a single case study", Nova Science Publishers, p. 22.

7 Protocol on the vulnerability assessment and support procedure used to facilitate the testimony of vulnerable witnesses, paras. 4-5. ICC-01/04-02/06-419-Anx3, dated 12 December 2014.
} 
impact of victim participation in the determination of substantive outcomes consistent with victim-oriented justice (Moffett, 2014) ${ }^{1}$. Hence, It is also enshrined in the Article 9/a of the CCP which reads that judicial authorities shall "guarantee that victims of criminal offences are treated with respect for their human dignity and are protected from being revictimized." This provision is fully in compliance with Directive 2012/29/EU and Council of Europe recommendations in the way that victims of crime, especially vulnerable ones (children and sexual crimes victims) should be protected from victimization, retraumatization, from intimidation and from retaliation, receive appropriate support to facilitate their recovery, and should be provided with sufficient access to justice. The concept of "protection from being re-victimizes" means to prevent future episodes from recurring. As a consequence the authorities are bound by the principle of protection and prevention.

However, it is of great concern that the CCP lacks a detailed procedure in relation to the characteristics that competent authorities operating within the context of criminal proceedings or any service coming into contact with victims, such as victim support or restorative justice ${ }^{2}$ services, should take into account when assessing a victim's need for protection and support. Up to date, there is an uncertainty among the Judges on whether the Court, the Office of the Prosecutor or the Registry performs any "Victim's Need Evaluation/Assessment" in relation to the participation of victims in order to find out their needs and concerns ${ }^{3}$ not only during the trial but also outside it. In it a requirement of the Directive in its para. 55 that "some victims are particularly at risk of secondary and repeat victimisation, of intimidation and of retaliation by the offender during criminal proceedings. It is possible that such a risk derives from the personal characteristics of the victim or the type, nature or circumstances of the crime. Only through individual assessments, carried out at the earliest opportunity, can such a risk be effectively identified. Such assessments should be carried out for all victims to determine whether they are at risk of secondary and repeat victimisation, of intimidation and of retaliation and what special protection measures they require". Hence, there is a high rate of vulnerable victims (mostly victims of human trafficking, organised crime, violence in close relationships - domestic violence, sexual violence or exploitation, gender-based violence, hate crime, and victims with disabilities and child victims) who tend to experience re-victimisation, intimidation and retaliation. This is also due to the low related convictions of the perpetrators especially on trafficking of human beings cases ${ }^{4}$. An adequate assessment of risk should demonstrate a strong presumption that those victims will benefit from special protection measures. ${ }^{5}$

\footnotetext{
${ }^{1}$ Moffett, L. (2014), "Justice for victims before international criminal court", Routledge Research in International Law. ${ }^{2}$ Article 2(1) of the Directive, 'restorative justice' means any process whereby the victim and the offender are enabled, if they freely consent, to participate actively in the resolution of matters arising from the criminal offence through the help of an impartial third party.

3 A questionnaire on "Victim Assessment » was performed in the District Court on Shkodra, Albania in November 2017. The purpose of this questionnaire is to evaluate the importance, the status and the implementation of victims/witnesses' rights in the criminal proceedings (organised crime, human and drugs trafficking, homicides) from the perspective of Judges and Prosecutors. 50\% of the Judges interviewed noted that there is no assessment performed in relation to victims or witnesses, while $50 \%$ of Judges, Prosecution and Registry staff replied positively.

${ }^{4}$ European Commission, Albania 2018 Report, Accompanying the document, Communication from the Commission to the European Parliament, the Council, the European Economic and Social Committee and the Committee of the Regions 2018 Communication on EU Enlargement Policy, April 17, 2018, SWD(2018) 151 final, p. 35.

${ }^{5}$ Directive para 57.
} 


\section{Challenges to ensure efficiency and prospective considerations}

The Albanian criminal justice system - from an international and regional context of victim participation - is not yet at the point where investigative and judicial functions are perfectly operating in terms of implementation modalities and the impact that victims participation will have in criminal proceedings ${ }^{1}$.

In a traditional adversarial justice system, the presence of the victim or his or her legal representative throughout the hearings would be seen as a burden to the proceedings which might create delays and further costs for the court. This myth has not been widely ${ }^{2}$ shared by the Council of Europe's countries and by international tribunals and courts ${ }^{3}$ which consider the recognition of victims' participation and their right as a contribution to the justice process. However, it is essential that the Judges and Prosecutors in Albania should guarantee and give careful consideration to understanding the role of the victims in the criminal proceedings from the victims' perspective. Thus, in order for the victim or his or her legal representative to be in a position to plead that a matter is relevant to the interest of victim, she or he must be in "a position to access all relevant information about the case, including by requesting access to confidential information where necessary, and participating in hearings" 4 . Despite the new amendments, the District Courts in particular, face greater obstacles regarding protective support and assistance services for victims than courts in any other European or Balkan countries. For instance, Serbia is developing a national system of victim support services which comply with EU Directive 2012/29/EU as part of the accession process ${ }^{5}$. This national support system is inexistent in Albania. Both the 2016 and 2018 European Commission Progress Reports for Albania noted that "[t]he vast majority of cases involving vulnerable groups are still handled by civil society organisations, with donor support". 6

The limited professional and financial capacities to provide assistance and protection are also a challenge, despite the fact that the Anti-Mafia Law ${ }^{7}$ established a 'Special Fund for

\footnotetext{
${ }^{1}$ International Federation of Human Rights (FIHR) (2014), Five Myths about Victim Participation in ICC proceedings, p. 6; Expert Initiative on Promoting Effectiveness at the International Criminal Court (Advance Copy, May 2014) (Expert Initiative), p 175-201; C. Van den Wyngaert, Victims Before International Criminal Courts: Some Views and Concerns of an ICC Trial Judge, Case Western Reserve Journal of International Law 44: 475-495; C. Chung, Victims' Participation at the International Criminal Court: Are Concessions of the Court Clouding the Promise?, Northwestern Journal of International Human Rights, 6(3):459-545; War Crimes Research Office (American University), Victim Participation at the Case Stage of the Proceedings (February 2009), http://www.wcl.american.edu/warcrimes/icc/documents/

WCROReportonVictimParticipationattheCaseStageofProceedingsFebruary2009.pdf.

${ }^{2}$ Article 8

Right to access victim support services

1. Member States shall ensure that victims, in accordance with their needs, have access to confidential victim support services, free of charge, acting in the interests of the victims before, during and for an appropriate time after criminal proceedings. Family members shall have access to victim support services in accordance with their needs and the degree of harm suffered as a

3 Judge Sir Adrian Fulford, The Reflections of a Trial Judge (2010), available at: http://www.iccnow.org/documents/Reflections of a Trial Judge ASP New York 6 December 2010.pdf para 20.

${ }^{4}$ International Federation of Human Rights (FIHR) (2014), Five Myths about Victim Participation in ICC proceedings, p. 11.

${ }^{5}$ Victim Support Europe, (2017),"Overview of Existing Victim Support Services in Serbia".

${ }^{6}$ European Commission, Albania Progress Report, 2016, p. 67 and 2018, p. 30.

7 Article 37(2)(a),(b), Law 10192, dated 3.12.2009, "On Preventing and Clamping Down on Organised Crime, Trafficking and Corruption Through Preventive Measures Against Assets", lastly amended on by Law no. 70/2017.
} 
the Prevention of Criminality' or the 'Special fund on Preventing Organised Crime' which are meant to serve for the development of witness protection programs and assistance to the victims of organized crime and human trafficking. The lack of professional expertise and human resources derives from the weak capacity of criminal justice actors and institutions. For instance, there is only one case in 2011, where a victim of trafficking in human beings was granted compensation. While in 2017 no victim benefited from the right to financial compensation ${ }^{1}$. The European Commission for the Efficiency of Justice (CEPEJ) stated in its 2016 Report (question 34) that there is no data in relation to the evaluation of the recovery rate of the damages awarded by courts to victims. The introduction of new provisions in the CCP on victims compensation requires experienced victim representatives who know how to ask for compensation and also the establishment of a special state fund to compensate victims of serious crimes such as trafficking or organized crime.

Further, the lack of adequate legal provisions addressing victims' needs, the limited public information on the role and purpose of witness testimony, the deficiency of assessing a substantial danger of threat or intimidation in a small country when 'everyone knows everyone'2, and the delays affecting the length of criminal proceedings for various reasons (lack of addresses, refusal to testify for fear of reprisals, intimidation or revenge) are serious indicators of the incapability of Albanian judicial bodies to provide the necessary assistance and protection to victims.

The 2016 European Commission Report on Albania noted that the implementation of basic procedural rights in practice, such as the right to information, access to legal aid and specific safeguards for victims ${ }^{3}$ of crime is ineffective and the competent authorities need to increase the level of protection provided by the existing legislation (European Commission, Albania Progress Report, 2016:67). With new amendments in the CCP aiming to strengthen and improve the legal status of victims in criminal proceedings in the Albanian Courts ${ }^{4}$, still there are no legal provisions in place which ensure the victims' right to access assistance and support services including procedural, emotional and psychological support, in proportion to their needs ${ }^{5}$.

Subsequently, the non-existence of a Victim and Witness Unit (VWU) as a neutral support mechanism to assist victims at all stages of the judicial process - from investigation to a final judgment - might consider apprehensive, ineffective and nonbinding the new criminal procedural provisions on courts or other public authorities. The immediate need to create this special unit or section within the District Courts and the

\footnotetext{
${ }^{1}$ European Commission, Albania Progress Report, 2018:, p. 35.

2 In the EU Directive, para. 40 it states that "Although the provision of support should not be dependent on victims making a complaint with regard to a criminal offence to a competent authority such as the police, such authorities are often best placed to inform victims of the possibility of support. Member States are therefore encouraged to establish appropriate conditions to enable the referral of victims to victim support services, including by ensuring that data protection requirements can be and are adhered to. Repeat referrals should be avoided".

${ }^{3}$ Victims with dual status, include also their role as a witness.

${ }^{4}$ Raport për projektligjin "për disa shtesa dhe ndryshime në ligjin nr. 7905, datë 21.3.1995, "kodi i procedurës penale i republikës së shqipërisë", i ndryshuar", p. 1, 21 March 2017.

${ }_{5}$ According to the questionnaire, op.cit. questionnaire, most of the Judges, Prosecutors and Registry staff replied to question 4 that there is no training or seminar for Judges and Prosecutors in relation to the implementation of the 2017 amendments and how the rights of the victims should be addressed in the proceedings.
} 
Court of Serious Crime is a major demand for the adequate implementation of the legal provisions in the CCP. The VWU will also be responsible to take appropriate measures to protect the safety, physical, psychological well-being, dignity and privacy of victims; including financial compensation to victims of crime.

Additionally, it may be important to ensure that a quality assessment is carried out in practice by the Court with the view to address the needs and concerns of the victims. In compliance with para. 56 of the Directive, the individual assessment should take into account the following:

- the personal characteristics of the victim such as his or her age, gender and gender identity or expression, ethnicity, race, religion, sexual orientation, health, disability, residence status, communication difficulties, relationship to or dependence on the offender and previous experience of crime;

- the type or nature and the circumstances of the crime such as whether it is a hate crime, a bias crime or a crime committed with a discriminatory motive, sexual violence, violence in a close relationship, whether the offender was in a position of control, whether the victim's residence is in a high crime or gang dominated area, or whether the victim's country of origin is not the Member State where the crime was committed.

The process of familiarization, as a particular form of support to victims (same applies to victims with dual status i.e victim-witness, and witnesses) who come to testify before a Court, is inexistent. In addition, there is no protocol or policy which includes informing the victims or witnesses on their rights, responsibilities, confidentiality, support and trial's procedure when they arrive at the Court to testify. ${ }^{1}$ The practice of familiarization would make it possible that this process would be under a WWU's responsibility, in consultation with the Office of the Prosecutor and would include as follows:

a. Assisting the victim to understand fully the court proceedings and the role that the parties and the participants play in them;

b. Reassuring the victim about his or her role in the proceedings before the Court;

c. Ensuring that victim clearly understands he or she is under a strict legal obligation to tell the truth when testifying;

d. Explaining to the victim the process of examination first by the Prosecution and subsequently by the Defence;

e. Discussing matters that are related to the security and safety of the victims in order to determine the necessity of applications for special support and protection before the Court; and,

f. Making arrangements with the Prosecution in order to provide the victims with an opportunity to acquaint himself or herself with the Prosecutor others who may examine the witness in Court.

Furthermore, in order to enhance the confidence of victims in the criminal justice system and to have adequate regard to the physical, psychological, material and social harm suffered by victims, ${ }^{2}$ the Court should propio motu, in coordination with the Office of the

1 Op. cit.

${ }^{2}$ Council of Europe, Recommendation No. R (96) 8 of the Committee of Ministers to member states on Crime Policy in Europe in a Time of Change. 
Prosecutor and the Registry, establish "A Victim/Witness Information Form" in order to provide operational support. This is also important in the context of the potential cooperation that the Courts in Albania might have with the Kosovo Special Chambers in the context of victim participation, given that some victims might reside in Albania. Their participation in the criminal proceedings is fundamental to the mandate of the Kosovo Specialist Chambers. Therefore, intimidation or retaliation by the offender(s) should be limited by carrying out proceedings in a coordinated and respectful manner, enabling victims to establish trust in the Specialist Chambers but also in national authorities.

Even though the VWU might not address all the needs of victims and witnesses, its creation would definitely improve the victims and witnesses participation in criminal proceedings and would positively influence the successful outcome of a trial. At least, victim interaction with competent authorities should be as easy as possible whilst limiting the number of unnecessary interactions the victim has with them through, for example, video recording of interviews, allowing its use in court proceedings, and also taking measures to limit distress during court proceedings in particular as a result of visual contact with the offender, his or her family, associates or members of the public.

The active personal participation in criminal proceedings of the victims promotes also the mediation and victim-offender reconciliation ${ }^{1}$ in penal matters by facilitating communication with the offender in order to obtain apology and reparation ${ }^{2}$.

To conclude, the adoption of a victims' law or policy would be a solution and a starting point for a more comprehensive guideline to clearly establish not only the legal position of victims and their rights but also the institutional responsibility to address the support, protection and reparation or compensation needs.

\section{Conclusion}

Protection and prevention are two approaches to fair treatment for the victims of crime in order to assist them get past the pain and return to a dignified and contributory life within their communities. The implementation of a credible and comprehensive policy law in order to address the position of the victims and their rights is important for the transparency and strengthening of the criminal justice system which aims at holding offenders accountable while ensuring protection of the rights of the victims and witnesses of crime. ${ }^{3}$ Granting a legal standing to victims should allow them during proceedings to address the defendant and the court, ask questions and make statements but also appeal final Court decisions.

\footnotetext{
${ }^{1}$ Council of Europe, Recommendation No. R (85) 11 of the Committee of Ministers to member states on the Position of the Victim in the Framework of Criminal Law and Procedure.

2 Council of Europe, Recommendation No. R (99) 19 of the Committee of Ministers to member states concerning mediation in penal matters.

${ }^{3}$ Report on the 2016 Commission Report on Albania (2016/2312(INI)), Committee on Foreign Affairs, Rapporteur: Knut Fleckenstein A8-0023/2017, February 3, 2017, para. 5.
} 
Given the experience of Serbia ${ }^{1}$, identifying the existing services that operate in Albania will be the first step in advancing towards the full implementation of the new provision on victims in the CCP and of the requirements of the Victims' Rights Directive, and ensuring adequate services to all victims of crimes on the entire territory of Albania. This would require also the creation of a comprehensive database of victim support services in Albania to enable victims to identify the most appropriate services which should be identifiable through different criteria such as location, type of victimization and type of service.

Institutional re-organisation and cooperation, and creation of a special unit within the Courts are major requirements without which the new amendments will remain inefficient and ineffective. Such a special unit will be responsible for monitoring the proper implementation of the legal provisions related to the victims in practice. Institutional and human resource capacities are also necessary for the well-functioning of the unit. The Albanian decision-making institutions in cooperation with the judicial organs and NGOs working with victims should take courageous measures to facilitate victims' access to courts particularly for women (European Commission, Albania Progress Report, 2018:29) and allocate adequate resources to enable the courts to provide remuneration and compensation. Lastly, systematic and adequate statistical data collection by the judicial authorities, by law enforcement agencies, by healthcare and social welfare services and by public and non-governmental victim support or restorative justice services working with victims of crime is required as an essential component of effective policymaking.

\section{References}

Code of Criminal Procedure

Constitution of the Republic of Albania

Council of Europe Committee of Ministers, Recommendation R. (87)21 on Assistance to Victims and the Prevention of Victimisation, 17 September 1987

Council of Europe Convention on Action against Trafficking in Human Beings (CETS No. 197)

Council of Europe, Recommendation No. R (85) 11 of the Committee of Ministers to member states on the Position of the Victim in the Framework of Criminal Law and Procedure

Council of Europe, Recommendation No. R (96) 8 of the Committee of Ministers to member states on Crime Policy in Europe in a Time of Change

Council of Europe, Recommendation No. R (97) 13 of the Committee of Ministers to member states concerning Intimidation of Witnesses and the Rights of the Defence

Council of Europe, Recommendation No. R (99) 19 of the Committee of Ministers to member states concerning mediation in penal matters

\footnotetext{
${ }^{1}$ Overview of existing victim support services in Serbia, p. 33, para. 54.
} 
Council of Europe, Recommendation No. R. (83)7 of the Committee of Ministers to member States on participation of the public in crime policy

Council of Europe, Recommendation Rec (2006)8 of the Committee of Ministers to Member States on Assistance to Crime Victims, 14 June 2006

Council of Europe, Recommendation Rec(2000)19 of the Committee of Ministers to Member States on the Role of Public Prosecution in the Criminal Justice System, 6 October 2000

Council of Europe, Recommendation Rec(2005)9 of the Committee of Ministers to member states on the protection of witnesses and collaborators of justice

Council of Europe, the Criminal Law Convention on Corruption (ETS No. 173)

Directive 2012/29/EU of the European Parliament and of the Council of 25 October 2012 establishing minimum standards on the rights, support and protection of victims of crime, and replacing Council Framework Decision 2001/220/JHA

European Commission, Albania 2016 Report, Accompanying the document, Communication from the Commission to the European Parliament, the Council, the European Economic and Social Committee and the Committee of the Regions 2016 Communication on EU Enlargement Policy, Brussels, November 9, 2016, SWD(2016) 364 final

European Commission, Albania 2018 Report, Accompanying the document, Communication from the Commission to the European Parliament, the Council, the European Economic and Social Committee and the Committee of the Regions 2018, Communication on EU Enlargement Policy, Strasbourg, April 17, 2018, SWD(2018) 151 final.

European Convention on Mutual Assistance in Criminal Matters (ETS No. 182).

Internal Rules of the Extraordinary Chambers in the Courts of Cambodia (ECCC)

Law No. 35/2017 "On amending the Code of Criminal Procedure"

Law no. 37/2017 Code of Criminal Justice for Children

Law No. 95/2016, "On the Organisation and Functioning of Institutions for Combating Corruption and Organised Crime".

Report on the 2016 Commission Report on Albania (2016/2312(INI)), Committee on Foreign Affairs, Rapporteur: Knut Fleckenstein A8-0023/2017, February 3, 2017.

Rome Statute of the International Criminal Court

Rules of Procedure and Evidence of the Kosovo Specialist Chambers and the Specialist Prosecutor's Office

Statute of the Special Tribunal for Lebanon

UN Convention against Corruption (UNCC)

United Nations Convention against Transnational Organised Crime (UNTOC) 
United Nations Declaration of Basic Principles of Justice for Victims of Crime and Abuse of Power A/RES/40/34, 29 November 1985

Vendime Unifikuese Penale 1999-2015, Vendim Unifikues nr.1, datë 25.01.2007 - Ligji 9284/2004

Agolli, T., Georgieva, I., \& Stevkovski, B. (August 2015). Fight against Trafficking in Human Beings and Organised Crime - Phase 2 (THB/IFS/2), Assessment of the National and Transnational Referral Mechanism for Victims of Trafficking in Albania.

Allegrezza, S. (2015), Victim's Statute Within Directive 2012/29/EU, in L. Lupária (ed.), Victims and criminal justice. European standards and national good practices

Anastasi, A. (2017). Te Drejtat e Viktimave te Trafikimit te Qenieve Njerezore ne Procesin Penal (neni 58, 58/b te Kodit te Procedures Penale). In S. Simoni, A. Anastasi, \& E. Imeraj, Komentar I Veprave Penale te Trafikimit te Qenieve Njerezore - Te drejtat e viktimave te trafikimit gjate procesit penal ( $\mathrm{p}$. 57). Tirana: OSCE.

C. Chung, Victims' Participation at the International Criminal Court: Are Concessions of the Court Clouding the Promise?, Northwestern Journal of International Human Rights, 6(3):459-545.

C. Van den Wyngaert, Victims Before International Criminal Courts: Some Views and Concerns of an ICC Trial Judge, Case Western Reserve Journal of International Law 44: 475-495.

Cody, S., Koenig, A., and Stoven, E., (2015) "The Victims' Court: A Study of 622 Victim Participants at the International Criminal Court"

Doak, J., (2005) “Victims' Rights in Criminal Trials: Prospects for Participation”, Journal of Law and Society, Vol. 32, Issue 2, pp. 294-316.

Erez, E., V. Roberts, J. V., (2014) "Victim Input at Sentencing”, p. 5425 in G. Bruinsma, D. Weisburd, (eds) "Encyclopedia of Criminology and Criminal Justice", Springer.

European Commission for the Efficiency of Justice, European Judicial Systems, Efficiency and Quality of Justice, CEPEJ Studies No. 23, Edition 2016 (data 2014). https://rm.coe.int/european-judicialsystems-efficiency-and-quality-of-justice-cepej-stud/168079048e

International Federation of Human Rights (FIHR) (2014), Five Myths about Victim Participation in ICC proceedings Expert Initiative on Promoting Effectiveness at the International Criminal Court (Advance Copy, May 2014) (Expert Initiative), p 175-201.

Successful Conclusion of Final ICTY Legacy Conference”, 22 to 24 June 2017. Mr Miguel de Serpa Soares, Under-Secretary-General for Legal Affairs and United Nations Legal Counsel, delivered the Closing Address, reflecting on the "moral legacy" of the ICTY. http://www.icty.org/en/press/successfulconclusion-of-final-icty-legacy-conference

Tibori-Szabó K., Hirst M. (2017) (eds) Victim Participation in International Criminal Justice. International Criminal Justice Series, Vol 11. T.M.C. Asser Press, The Hague

War Crimes Research Office (American University), Victim Participation at the Case Stage of the Proceedings (February 2009),

http://www.wcl.american.edu/warcrimes/icc/documents/WCROReportonVictimParticipationattheCaseStage ofProceedingsFebruary2009.pdf. 